\title{
Angelman syndrome : A rare case report
}

\begin{abstract}
:
Angelman syndrome (AS) is a rare neurodevelopmental disorder characterized by severe intellectual disability, speech delay, dysmorphic features, cognitive impairment, seizures as well as a unique behaviour with an inappropriate happy demeanor. This article discuss the case of an eight year old male patient with the chief complain of dental pain but presented with the signs of AS. He appeared hyperactive and easily excitable with an unusual laughing facial expression. His speech was impaired and showed unusual fascination towards water. Metabolic screening tests and brain Magnetic Resonance Imaging (MRI) revealed no abnormality. Genetic analysis is pathognomonic for Angelman Syndrome.
\end{abstract}

Key words: Angelman Syndrome; Neurogenetic Disorder; Myoclonus; Epilepsy

\section{Introduction:}

Angelman Syndrome (AS) was first described in 1965 by English paediatrician Dr. Harry Angelman as "happy puppet" syndrome.[1] It is a neurogenetic disorder caused due to loss of expression of maternal UBE3A protein, encoded on chromosome 15q11.2-13.1, which result in distinctive phenotype.[2]

Development delays are usually evident within the first year of life. The behavioural features include easily provoked laughter, short attention span, hypermotoric behaviour, mouthing of objects, sleep disturbance and affinity towards water. Movement disorders include jerkiness, ataxic gait and tremors.[3] The incidence of AS is 1:10,000 to 40,000 with no gender predilection. [4-5] This case describe a child with AS.

\section{Case Report:}

An eight year old male patient reported with complaint of pain in maxillary left posterior region since 3 days. Pain was spontaneous in origin, dull and continuous in nature. It aggravated on its own and relieved by taking medication.

Child was hyperactive and presented with unique behaviour of constant smiling, frequent laughing and excitability. He showed fascination to water/crinkly items. He could walk on

\begin{tabular}{|l|l|}
\hline \multicolumn{2}{|c|}{ Access this article online } \\
\hline \multirow{2}{*}{$\begin{array}{l}\text { Website: } \\
\text { www.ujds.in }\end{array}$} & Quick Response Code \\
\hline $\begin{array}{l}\text { DOI: } \\
\text { https://doi.org/10.21276/10.21276/ujds.2020.6.2.8 }\end{array}$ \\
\hline
\end{tabular}

his own but with shrugged shoulders and slightly raised arms flexed at the elbows (Figure 1).

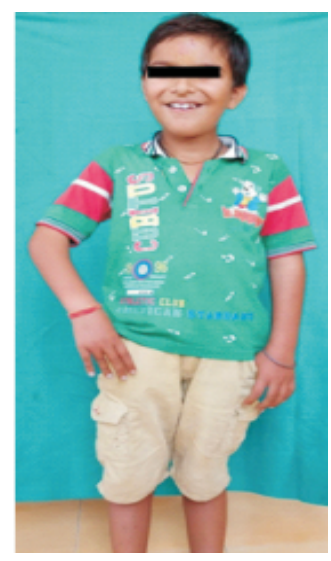

Figure 1: Profile picture of a child with Angelman syndrome.

${ }^{1}$ GAUR B, ${ }^{2} \mathrm{~K}$ R NAIR G, ${ }^{3}$ MOHAN V, ${ }^{4}$ KUMAR GUPTA S

${ }_{1,2,3}$ Department of Oral Medicine \& Radiology,

K. D. Dental College \& Hospital, Mathura

${ }^{4}$ Department of Pedodontics \& Preventive Dentistry,

K. D. Dental College \& Hospital, Mathura

Address for Correspondence: Dr. Balkrishn Gaur Surendra Nagar, Aligarh, Uttar Pradesh, India 202001

E-mail: balkrishn2408@gmail.com

Received : 07 July 2020, Published : 31 August 2020

How to cite this article: Gaur B., K. R. Nair G., Mohan V., Kumar Gupta S. (2020). Angelman Syndrome: A Rare Case Report. UNIVERSITY JOURNAL OF DENTAL SCIENCES, 6(2): 79-2. 
He was $112 \mathrm{~cm}$ tall and $23.2 \mathrm{~kg}$ in weight. He was the third child of nonconsanguineous healthy parents. Also, there was no history of allergy and seizures but IQ level was below than normal. He was born at the time via vaginal delivery with normal Appearance, Pulse, Grimace, Activity, and Respiration (APGAR) score. He had a happy face and the parents noticed his hyperactivity at the age of 5 years. They reported that he was able to sit at the age of 7 months and was able to walk independently at the age of 14 months. They also described his disturbed sleep-wake cycle wherein the patient sleeps late at night and wakes up early morning.

On physical examination, the child presented with dolicocephalic head, flat occiput, mandibular prognathism, clubbing in fingers of both the hands, drooling of saliva and difficulty in articulated speech. Intraorally, patient revealed partially bifid tongue, multiple carious teeth and mammelons in incisors (Figure 2 and 3 ). Overall the child was hyperactive with impaired speech, sleep disturbance, excitability and fascination with water. His muscle tone, force and deep tendon reflexes were normal. Besides, he could walk and run independently.

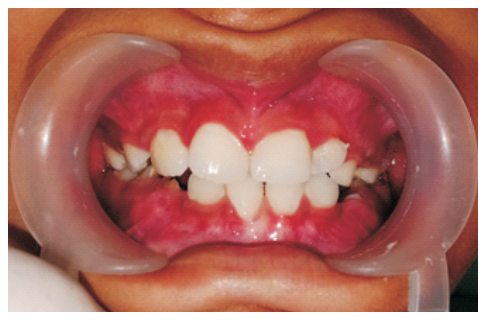

Figure 2: Intraoral image

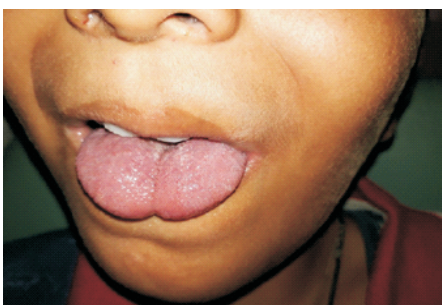

Figure 3: Image reveal bifid tongue

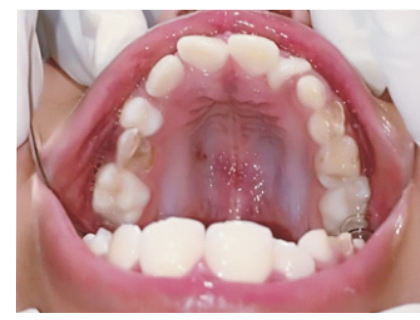

Figure 4: Pre operative intraoral maxillary view

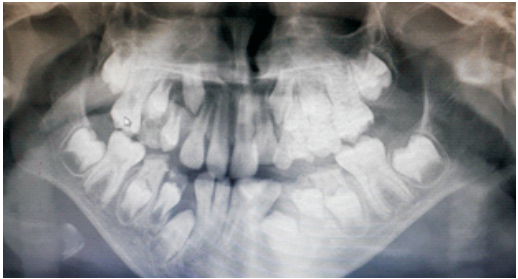

Figure 5: Panoramic view

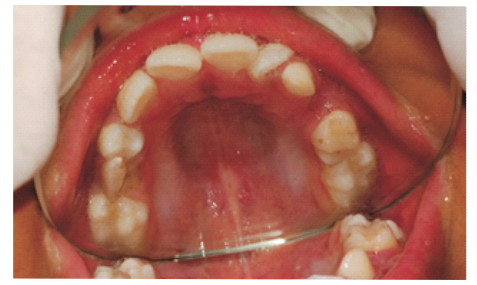

Figure 6: Post operative view reveals extraction irt. 64

Panoramic radiograph revealed multiple retained teeth, unerupted permanent teeth and reduced height of alveolar bone (Figure 5). Laboratory findings were normal. Electroencephalography (EEG), Electrocardiography (ECG), Chest radiograph and long bones radiographs appeared normal.

Treatment of the patient was planned out and approached systematically starting with oral prophylaxis along with continuous monitoring of periodontal health. This was followed by the extraction of deep carious teeth $64,74,75,84$, 85 (Figure 6). The patient was later subjected to orthodontic treatment for aesthetic correction.

Table-1: Clinical Features of Angelman Syndrome [3].

\begin{tabular}{|c|c|c|}
\hline Consistent & Frequent & Occasio nal \\
\hline $\begin{array}{c}\text { Functionally severe } \\
\text { intellectual } \\
\text { disability }\end{array}$ & $\begin{array}{l}\text { Microcephaly } \\
\text { with flat } \\
\text { occiput/occipital } \\
\text { groove }\end{array}$ & Scoliosis \\
\hline $\begin{array}{c}\text { Movement/balance } \\
\text { disorder }\end{array}$ & Seizures & $\begin{array}{l}\text { Hypopigmentati } \\
\text { on } \\
\end{array}$ \\
\hline Speech impairment & Abnormal EEG & $\begin{array}{c}\text { Increased } \\
\text { sensitivity to } \\
\text { heat }\end{array}$ \\
\hline \multirow[t]{5}{*}{$\begin{array}{l}\text { Behavioral } \\
\text { phenotype (easily } \\
\text { excited, happy, } \\
\text { frequent laughter, } \\
\text { hypermotoric) }\end{array}$} & $\begin{array}{l}\text { Gastrointestinal } \\
\text { difficulties } \\
\text { (feeding } \\
\text { problems, } \\
\text { gastroesophageal } \\
\text { reflux, } \\
\text { constipation) }\end{array}$ & $\begin{array}{l}\text { Growth } \\
\text { disturbance } \\
\text { depending on } \\
\text { genotype }\end{array}$ \\
\hline & $\begin{array}{l}\text { Fascination with } \\
\text { water or crinkly } \\
\text { items }\end{array}$ & $\begin{array}{l}\text { Ocular problems } \\
\text { (refractive and } \\
\text { alignment } \\
\text { errors) }\end{array}$ \\
\hline & $\begin{array}{l}\text { Mo uthing } \\
\text { behavior }\end{array}$ & \\
\hline & Ankle pronation & \\
\hline & $\begin{array}{c}\text { Sleep } \\
\text { disturbance }\end{array}$ & \\
\hline
\end{tabular}




\section{Discussion:}

AS can be diagnosed from 2 years of age up till adulthood due to lack of overtly distinctive phenotype presentations.[6] The peculiar behavioral profile mostly become evident in second and third years of life, that is when the most common dysmorphic features are observed.[7] In this case, parents of the patient identified the developmental delay when the patient was 3 years of age.

These patients are commonly referred as having "happy puppet syndrome" because of their happy disposition, frequent and inappropriate bursts of laughter along with the hand-flapping and trembling gait.[6]

Excessive salivation can be due to lack of swallowing which can cause drooling. It can also be caused by stomatitis or use of certain medications.[8] The child with AS presented high risk of caries incidence because of inability to maintain proper hygiene due to lack of motor coordination and cognitive impairment; regular use of medications that can be sugared and cause xerostomy; an uncontrolled and cariogenic diet; and difficulty in accessing regular professional dental care.[9] The patient who have AS shows craniofacial abnormalities (Table 1) including microcephaly, high-arched palate, tongue protrusion with thrusting, macroglossia, diastemas, excessive chewing behavior, wide jaw and flat occiput, all of which contribute to potential airway difficulties in this patient population. However, even though our patient presented with few such abnormalities (Table 2) like wide mouth, abnormal teeth, tongue protrusion causing bifid tongue and mandibular prognathism, he fortunately did not experience any airway complications.

Impaired communication is mainly due to the symptoms of language deficit and mental retardation. Even our patient seemed mentally retarded with speech defect. Additionally, clinical features of AS include hyperactive tendon reflexes, sleep disturbances, short attention span, strabismus, obesity, sucking/swallowing disorders and history of epilepsy.

Gastrointestinal distress is one of the most critical issue that require clinical care for many individuals across all age groups in AS.[2] The medications for the same (if under any) may add in complexity to the anaesthesia management of the patient. Usually, the child with AS shows appearance of striking high voltage slow-wave activity is a frequent characteristic finding on EEG.[10] In our case report though, EEG and ECG findings were normal and gratefully no such complications arose.

\section{Conclusion:}

Angelman syndrome affected children present with myriad challenges to a clinician. Apart from behavioural and medical consideration, oral intervention is also requisite. Multiple oral manifestations are presented in patients with Angelman Syndrome as a consequence to not just the syndrome but also the movement abnormalities like ataxia and myocopus which results in inability in maintaining proper oral hygiene. Behavioural modification and guidance is required for both the child and the parent to proceed with any dental procedure which is acceptable to the parent and of highest quality. Patient education, motivation and establishing a positive relationship with the child and his/her family should be the ideal motive to the clinician along with the establishment of Dental Home

Table 2: Oral manifestations of Angelman syndrome found in the dental literature[8]

\begin{tabular}{|c|c|c|c|c|}
\hline Author & Year & $\begin{array}{c}\text { Cases } \\
\text { (n) }\end{array}$ & $\begin{array}{c}\text { Age } \\
\text { (years) }\end{array}$ & $\begin{array}{c}\text { Oral } \\
\text { manifestations } \\
\text { murakami, et a1 }\end{array}$ 2008 \\
\hline Ramanathan, et \\
al
\end{tabular}




\section{Acknowledgment:}

Author would like to express his gratitude to the faculty of K. D. Medical \& Dental College for their support and help in diagnosing this syndrome.

\section{References:}

1. Jagath C. Ranasinghe, Damitha Chandradasa, Sanjaya Fernando, Uditha Kodithuwakku, D.E.N. Mandawala and Vajira HW Dissanayake. Angelman syndrome presenting with a rare seizure type in a patient with 15q11.2 deletion: a case report. Journal of Medical Case Reports. 2015;9:142

2. Ankita Prasad, Olivia Grocott, Kimberly Parkin, Anna Larson, Ronald L. Thibert. Angelman syndrome in adolescence and adulthood: A retrospective chart review of 53 cases. Am J Med Genet. 2018;176A:pp.1327-1334

3. Lynne M Bird. Angelman syndrome: review of clinical and molecular aspects. The Application of Clinical Genetics. 2014;7:pp.93-104

4. J Clayton-Smith, L Laan. Angelman syndrome: a review of the clinical and genetic aspects. J Med Genet. 2003;40:pp.87-95

5. Chunawalla Yusuf, Morawala Abdul, Jain Kapil, Naqiyaa Khandwawala. Angelman Syndrome: A Case Report. International Journal of Current Research. 2018;10(1):pp.63993-63996

6. Leonardo Campero. Happy Puppet Syndrome: A Case Report of Anesthetic Management. AANA Journal. 2018;86(1):pp.67-71

7. Marielza Fernández Veiga, Maria Betânia Pereira Toralles. Neurological manifestation and genetic diagnosis of Angelman, Rett and Fragile-X syndromes. J Pediatr (Rio J). 2002; 78 (Supl.1): pp.S55S62

8. José González-Serrano, Víctor Manuel Paredes-Rodríguez, Carlos González-Serrano, Gema Torrijos Gómez, Jorge A. Cano-Durán, Rosa María López-Pintor. Oral Manifestations in Angelman Syndrome: A Systematic Review of the Dental Literature. IOSR Journal of Dental and Medical Sciences. 2017;16(5):pp.73-77

9. Alexandra Mussolino de Queiroz, Talitha de Siqueira Melara, Paula Dariana Fernandes Ferreira, Marília Pacífico Lucisano, Andiara De Rossi, Paulo Nelson-Filho. Dental findings and special care in patients with Angelman syndrome: a report of three cases. Spec Care Dentist. 2013;33(1):pp.40-45

10. Karin Buiting. Prader-Willi Syndrome and Angelman Syndrome. American Journal of Medical Genetics Part C (Seminars in Medical Genetics). 2010;154C:pp.365-376 